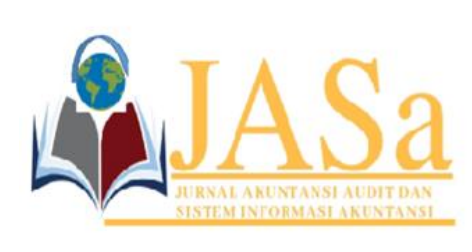

\author{
JASa (Jurnal Akuntansi, Audit dan Sistem Informasi Akuntansi) \\ Vol. 5 No.1/ April 2021 \\ ISSN 2550-0732 print / ISSN 2655-8319 online \\ DOI;10.36555/ jasa.v5i1.1605
}

\title{
ANALYSIS OF THE IMPLEMENTATION OF ACCOUNTING INFORMATION SYSTEMS TO IMPROVING THE PREPARATION OF FINANCIAL STATEMENTS IN THE SALES CYCLE OF OIL AND GAS COMPANIES
}

\author{
Ayi Astuti ${ }^{1}$, Indri Utami ${ }^{2}$, Mentari Puteri Pertiwi ${ }^{3}$ \\ Universitas Langlangbuana, Indonesia ${ }^{* 123}$ \\ ayivhuvhu@gmail.com ${ }^{* 1}$, indri.reisal@gmail.com² ${ }^{2}$ mentariputerii@gmail.com³
}

\begin{abstract}
This study aims to determine the role of accounting information systems in improving the quality of financial reporting and analyzing financial reports in the sales cycle following accounting information systems theory. The data analysis technique used is the descriptive analysis technique, namely how to analyze, interpret, and process oil and gas financial report data. Respondents in this study were one of the oil and gas companies in Bandung, namely PT. Puteramas Teguh Jaya by surveying 35 respondents. The type of data used in this research is qualitative data. Sources of data in this study are secondary data in the form of financial reports on oil and gas sales. Data collection techniques used in this study are interview techniques and documentation techniques regarding accounting information systems for sales financial reports. From the known research results, it is obtained as follows: Responses about the variables of this study are included in the high category, financial reports, and sales cycle The results of the analysis found that there is a significant relationship between accounting information systems and financial reports, including knowledge of entrepreneurial competence with stakeholder support. interests with a fairly close relationship. The results of the analysis also found that the accounting information system and it were found simultaneously to have a significant effect on the sales cycle.
\end{abstract}

Keywords: Accounting Information Systems, Financial Reports, Sales.

\section{INTRODUCTION}

Oil and gas (Migas) are strategic non-renewable natural resources controlled by the state following the mandate of Article 33 paragraph (2) and paragraph (3) of the 1945 Constitution. Oil and gas is a vital commodity that controls the lives of many people and has a role. important in the national economy so that its management must be able to provide maximum prosperity and welfare of the people. Oil and gas business activities provide added value significantly to sustainable national economic growth. The implementation of oil and gas business activities must be based on social economy, integration, benefits, justice, balance, equity, mutual prosperity and the welfare of the people at large, security, safety and legal certainty as well as being environmentally sound. In the last five years, Indonesia's oil fields have continued to age. With the current regional autonomy system, it is difficult for foreign oil companies to operate because they are dealing with petty kings in the regions. Meanwhile, domestic demand has exceeded production capacity. The government, in this case Pertamina, already has a refinery in Pangkalan Brandan, Dumai, Plaju, Balongan, Cilacap, Balikpapan, and Kasim / Papua. However, several new refineries need to be built shortly to meet domestic consumption demand which continues to show an increasing trend. The accounting information 


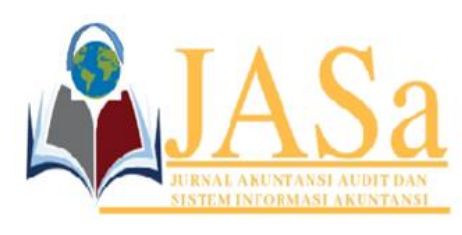

JASa (Jurnal Akuntansi, Audit dan Sistem Informasi Akuntansi)

Vol. 5 No.1/ April 2021

ISSN 2550-0732 print / ISSN 2655-8319 online

DOI; $10.36555 /$ jasa.v5i1.1605

system is a very important part of a company information system. In a company information system, the accounting information system is a part of an information system that deals more with financial data. According to (Azhar Susanto, 2015), Accounting Information Systems are components that are interconnected and work together to collect, process, store information to support decision-making coordination, control, and to provide an overview of activities within the company. This can be an opportunity for various companies to develop their business. To take advantage of these opportunities, Oil and Gas Companies must compete with other business actors. Oil and gas companies can do various ways to compete with competitors, one of which is by having an adequate Accounting Information System (SIA). An adequate AIS can help to produce quality information, so that it can be useful for making decisions, especially in financial reports. The aim is to pursue profits to increase company value based on the principles of managing the company effectively and efficiently as well as contributing to increasing economic activity globally. To achieve this goal, management needs an adequate Sales Accounting Information System that will be able to provide reliable information as well as a sales planning and control tool. Companies need to make improvements to the Accounting Information System so that periodic evaluations need to be done to find out any problems with the Accounting Information System that is being carried out. With an accounting information system in oil and gas companies, the delivery of financial information is more effective and accurate to users of financial reports. In achieving the company's goal of earning a profit, financial statements play an important role in achieving that goal. The success of the application of the accounting information system can be measured by the effectiveness of its presence in the preparation of financial statements. If the role of the accounting information system in its application is adequate, it will be able to produce effective and quality financial reports that will become the basis for decision making. Based on the description above, the researcher is motivated to conduct this research, first to find out the application of the accounting information system to financial reporting what arises in the sales cycle of the financial statements and to find out whether the financial statements of oil and gas companies have been presented effectively, especially those related to the sales cycle. According to (Widjajanto, 2016), the Accounting Information System is an arrangement of various record forms, equipment, including computers and their equipment as well as communication tools, implementation personnel, and closely coordinated reports designed to transform financial data into information needed by management. The accounting information system also plays a role as a safeguard for the company's assets. With the elements of control or checking in the accounting system. Frauds, irregularities, and mistakes can be avoided or traced so that they can be corrected. According to (Romney and Steinbart, 2014), information is data that has been managed and processed to provide meaning and improve the decision-making process. As with its role, users make better decisions as the quantity and quality of information increases. (According to Jogiyanto, 2015:) to support decisions to be made by management, management needs useful information. For each level of management with its different activities, information with different characteristics is needed. 


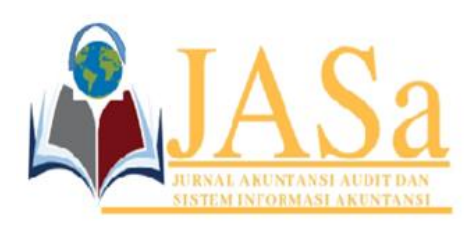

\author{
JASa (Jurnal Akuntansi, Audit dan Sistem Informasi Akuntansi) \\ Vol. 5 No.1/ April 2021 \\ ISSN 2550-0732 print / ISSN 2655-8319 online \\ DOI;10.36555/ jasa.v5i1.1605
}

According to (Romney, 2015) "Accounting Information Systems is an application of technology to capture, verify, store, sort and report data related to organizational activities". According to the (Indonesian Institute of Accountants 2012), "Financial Statements are part of a complete financial reporting process, which usually includes statements of financial position, profit and loss statements, reports of changes in financial position, notes and certain reports as well as explanatory material which is part of the integral of financial statements "

\title{
METHODS
}

According to (Siregar, 2016), the dependent variable is a variable that is influenced or becomes the result of other variables (independent variables). This variable is also often called the dependent variable, response variable or endogenous. In this study, all variables used an ordinal scale. Sources of data used in this study are primary data and secondary data. The method of data collection is by distributing 35 questionnaires to employees of PT. Puteramas Teguh Jaya. The sampling technique in this study is to use cluster random sampling of employees of PT. Puteramas Teguh Jaya by profession. This study uses validity and reliability tests to measure the validity and reliability of data and to test hypotheses. This research uses a descriptive verification method with data analysis techniques using SPSS.

\section{Pengujian Validity}

\section{RESULT AND DISCUSSION}

To test the validity of each question item, the scores for each question were correlated with the total score. By obtaining the validity index for each item, it can be seen which items do not meet the requirements in terms of their validity. The minimum requirement to fulfill the requirements is $r=0.3$ so that if the correlation between the items and the total score is less than 0.3 then the instrument is invalid (Sugiyono: 116). The results of the validity test of accounting information system variables are as follows:

Table 1. Results of the Validity Test of Accounting Information System Variables

\begin{tabular}{|c|c|c|c|}
\hline Question Item & $\begin{array}{c}\text { Validity } \\
\text { Coefficient }\end{array}$ & $\begin{array}{l}\text { Degree of } \\
\text { Freedom }\end{array}$ & Information \\
\hline Item 1 & .753 & 0.3 & Valid \\
\hline Item 2 & .632 & 0.3 & Valid \\
\hline Item 3 & .721 & 0.3 & Valid \\
\hline Item 4 & .711 & 0.3 & Valid \\
\hline Item 5 & .701 & 0.3 & Valid \\
\hline Item 6 & .611 & 0.3 & Valid \\
\hline Item 7 & .645 & 0.3 & Valid \\
\hline Item 8 & .621 & 0.3 & Valid \\
\hline Item 9 & .703 & 0.3 & Valid \\
\hline Item 10 & .603 & 0.3 & Valid \\
\hline Item 11 & .740 & 0.3 & Valid \\
\hline Item12 & .623 & 0.3 & Valid \\
\hline
\end{tabular}

Source: SPSS Data Processing Results 23 


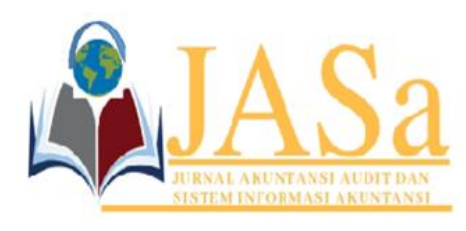

\section{JASa (Jurnal Akuntansi, Audit dan Sistem Informasi Akuntansi) \\ Vol. 5 No.1/ April 2021 \\ ISSN 2550-0732 print / ISSN 2655-8319 online \\ DOI; $10.36555 /$ jasa.v5i1.1605}

Based on table 1, the questions in point 1 and point 12 are valid because the validity coefficient is $\leq 0.3$. Then in further analysis the two question items can be used. The following are the results of the test results for the validity of the financial statement variables:

Table 2. Results of the Validity Test of Accounting Information System Variables

\begin{tabular}{cccc}
\hline Question Item & Validity Coefficient & Degree of Freedom & Information \\
\hline \hline Item 1 & .723 & 0.3 & Valid \\
Item 2 & .611 & 0.3 & Valid \\
Item 3 & .701 & 0.3 & Valid \\
Item 4 & .712 & 0.3 & Valid \\
Item 5 & .652 & 0.3 & Valid \\
Item 6 & .631 & 0.3 & Valid \\
Item 7 & .625 & 0.3 & Valid \\
Item 8 & .611 & 0.3 & Valid \\
Item 9 & .695 & 0.3 & Valid \\
Item 10 & .621 & 0.3 & Valid \\
Item 11 & .704 & 0.3 & Valid \\
Item12 & .636 & 0.3 & Valid \\
\hline
\end{tabular}

Source: SPSS Data Processing Results 23

Based on table 2, all statements on the work professionalism variable are declared valid because the validity coefficient is $\geq 0.3$. Following are the results of the validity test of the sales cycle variable:

\begin{tabular}{|c|c|c|c|}
\hline $\begin{array}{l}\text { Question } \\
\text { Item }\end{array}$ & Validity Coefficient & $\begin{array}{l}\text { Degree of } \\
\text { Freedom }\end{array}$ & Information \\
\hline Item 1 & .452 & 0.3 & Valid \\
\hline Item 2 & .514 & 0.3 & Valid \\
\hline Item 3 & .531 & 0.3 & Valid \\
\hline Item 4 & .371 & 0.3 & Valid \\
\hline Item 5 & .521 & 0.3 & Valid \\
\hline Item 6 & .667 & 0.3 & Valid \\
\hline Item 7 & .479 & 0.3 & Valid \\
\hline Item 8 & .679 & 0.3 & Valid \\
\hline Item 9 & .343 & 0.3 & Valid \\
\hline Item 10 & .553 & 0.3 & Valid \\
\hline Item 11 & .573 & 0.3 & Valid \\
\hline Item12 & .425 & 0.3 & Valid \\
\hline Item 13 & .458 & 0.3 & Valid \\
\hline Item 14 & .314 & 0.3 & Valid \\
\hline Item 15 & .465 & 0.3 & Valid \\
\hline Item 16 & .385 & 0.3 & Valid \\
\hline
\end{tabular}

Source: SPSS Data Processing Results 23 


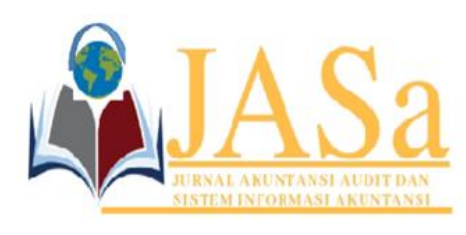

JASa (Jurnal Akuntansi, Audit dan Sistem Informasi Akuntansi)

Vol. 5 No.1/ April 2021

ISSN 2550-0732 print / ISSN 2655-8319 online

DOI; $10.36555 /$ jasa.v5i1.1605

Based on table 3 , all statements on the sales cycle variable are declared valid because the validity coefficient is $\geq 0.3$.

\section{Reliability Testing}

Table 3 Reliability Test Results

Reliability Statistics

\begin{tabular}{|c|c|c|}
\hline Vaniabel & $\begin{array}{c}\text { Cronbach's } \\
\text { Alphä }\end{array}$ & $\mathrm{N}$ of ltems \\
\hline accounting information s & stem 853 & 12 \\
\hline financial statements & .870 & 12 \\
\hline sales cycle & 864 & 16 \\
\hline
\end{tabular}

Source: SPSS Data Processing Results 23

Reliability testing in this study used Cronbach's Alpha. This coefficient is the reliability coefficient that is most often used, because this coefficient describes the variance of items for either true, false, or non-format formats such as the Likert scale. The reliability value is said to be reliable if the value is more than 0.6. As seen in Table 3 above all variables above 0.6

\section{Hypothesis test}

To find out whether or not there is a direct influence between the independent variable on the intervening and the intervening variable on the dependent, as well as the indirect effect of the independent variable on the dependent through intervening, a path analysis test, was carried out using SPSS 23, namely the causal step strategy and the product of coefficient. . In the causal step strategy, the hypothesis criterion ( $\mathrm{Ha})$ is accepted if Sig $<0.05$ is for direct effect either simultaneously (F-count) or partially, coupled with looking at the $t$ value to see the partial effect, namely $t$-count $>t$-table. To see the significance of the indirect effect, the Product of Coefficient strategy is used by looking at the $z$ value $>1.96$, although if from independent to significant intervening and intervening to dependent is also significant, it can be assumed that there is an indirect effect of the independent to dependent variables. The following are the results of the path analysis test: 


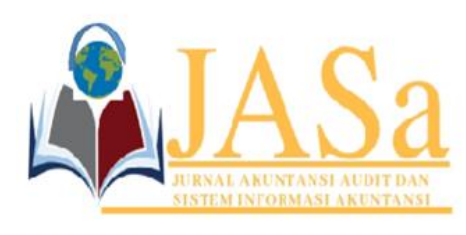
JASa (Jurnal Akuntansi, Audit dan Sistem Informasi Akuntansi)
Vol. 5 No.1/ April 2021
ISSN 2550-0732 print / ISSN 2655-8319 online
DOI; $10.36555 /$ jasa.v5i1.1605

\begin{tabular}{|c|c|c|c|c|c|}
\hline \multirow[t]{2}{*}{ Model } & \multicolumn{2}{|c|}{$\begin{array}{l}\text { Unstandardized } \\
\text { Coefficients }\end{array}$} & \multirow{2}{*}{$\begin{array}{c}\text { Standardized } \\
\text { Coefficients } \\
\text { Beta }\end{array}$} & \multirow[t]{2}{*}{$t$} & \multirow[t]{2}{*}{ Sig. } \\
\hline & $\mathrm{B}$ & Std. Error & & & \\
\hline (Constant) & 38,201 & 4,362 & & 8,758 & .000 \\
\hline accounting information system & $\mathrm{n} \quad, 558$ & ,069 & ,631 & 8,070 &, 000 \\
\hline
\end{tabular}

Source: SPSS Data Processing Results 23

Based on Table 4, it is known that the accounting information system variables significantly affect the financial statements directly with a Sig value of $0.000(<0.05)$ and the value of $t$-count $>t$-table $(8,070>1.96)$. Next is to look at the accounting information system analysis of financial reports in the sales syllus which is presented in the table below:

Table 5 accounting information systems, financial reports affect the cycle

\begin{tabular}{llrrrr}
\hline Model & $\mathrm{R}$ & R Square & $\begin{array}{c}\text { Adjusted R } \\
\text { Square }\end{array}$ & $\begin{array}{c}\text { Std. Error of the } \\
\text { Estimate }\end{array}$ \\
\hline 1 &, $410^{\mathrm{a}}$ &, 169 & &, 151 & 4,548 \\
\hline
\end{tabular}

Source: SPSS Data Processing Results 2

In Table 5, it can be seen that the effect of AIS on the financial statements in the sales cycle simultaneously is $16.9 \%$ or the variability of the preference level which can be explained by SIA and financial reports is $16.9 \%$ and the rest is caused by other variables outside the model.

\section{Data Normality Test}

The normality test is carried out to determine whether the dependent, independent or both variables are normally distributed or not, if the regression model is not normally distributed, the conclusions from the $\mathrm{F}$ test and t test are still doubtful, because the $\mathrm{F}$ test and $\mathrm{t}$ test statistics in the regression analysis are derived from the normal distribution. In this study, the Kolmogorov-Smirnov one-sample test was used to test the normality of the regression model. 


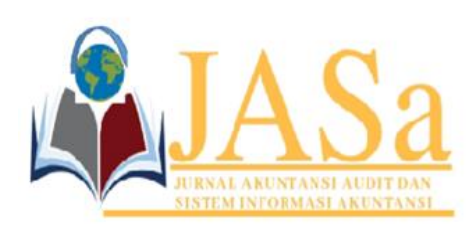

JASa (Jurnal Akuntansi, Audit dan Sistem Informasi Akuntansi)

Vol. 5 No.1/ April 2021

ISSN 2550-0732 print / ISSN 2655-8319 online

DOI; $10.36555 /$ jasa.v5i1.1605

Table 6. results of the normality test

One-Sample Kolmogorov-Smirnov Test

\begin{tabular}{|c|c|c|c|c|}
\hline & & ASI & $\begin{array}{l}\text { FINANCIAL } \\
\text { STATEMENTS }\end{array}$ & SALES CYCLE \\
\hline N & & 89 & 89 & 89 \\
\hline \multirow{3}{*}{ Normal Parameters 1.0} & Mèan & $40.273: 1$ & 74.1479 & 73.6531 \\
\hline & Std. Devviation & 7. 16142 & 8.44202 & \\
\hline & Absolute & .094 & .055 & .144 \\
\hline \multirow[t]{2}{*}{ Most Extreme Differences } & Positive & .059 & .037 & .144 \\
\hline & Negative & -.094 & -.055 & .082 \\
\hline Kolmogorov-Ŝmimov Z & & .887 & .523 & 1.363 \\
\hline Asymp. Sig (2-tailed) & & 484, & 968 & $.07 \overline{6}$ \\
\hline
\end{tabular}

a. Test distribution is Normal.

b. Calculated from data.

Source: SPSS Data Processing Results 2

In Table 6, it can be seen that the probability value (Asymp. Sig.) Obtained from the Kolmogorov-Smirnov test for the SIA variable is 0.484 , for financial statements is 0.988 , and the sales cycle variable is 0.076 . Because the probability value is still greater than the error rate of $5 \%(0.05)$, it is concluded that the regression model in this study is normally distributed. Besides, the normal graph of the P Plot of Regression Statistic can also be used to determine whether the data is normally distributed or not. If the data spread around the diagonal line and follows the direction of the diagonal line, it means that the regression model fulfills the assumption of normality.

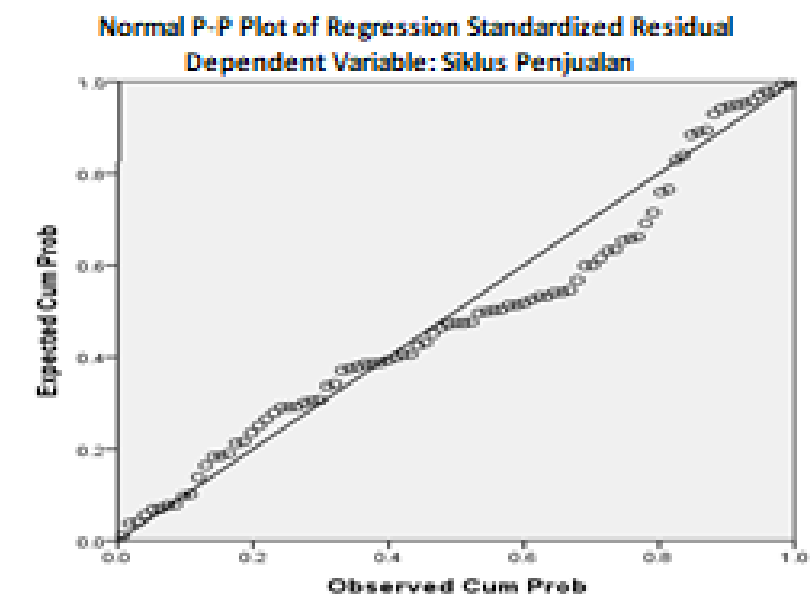

Figure 1. Normality test

Source: SPSS Data Processing Results 2 


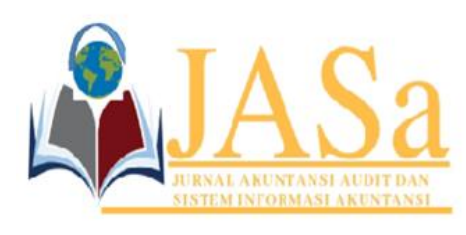

\section{JASa (Jurnal Akuntansi, Audit dan Sistem Informasi Akuntansi) \\ Vol. 5 No.1/ April 2021 \\ ISSN 2550-0732 print / ISSN 2655-8319 online \\ DOI; $10.36555 /$ jasa.v5i1.1605}

\section{Uji Multikolinearitas}

Multicollinearity means that there is a strong relationship among some or all of the independent variables in the regression model. If there is multicollinearity, the regression coefficient becomes uncertain, the error rate becomes very large and is usually marked by a very large determination coefficient value but on partial testing, there is none, or if there are very few significant regression coefficients. In this study, the value of variance inflation factors (VIF) was used as an indicator of the presence or absence of multicollinearity between the independent variables. For the multicollinearity test, it can be seen in table 7 .

Table 7. Multicollinearity Test Results

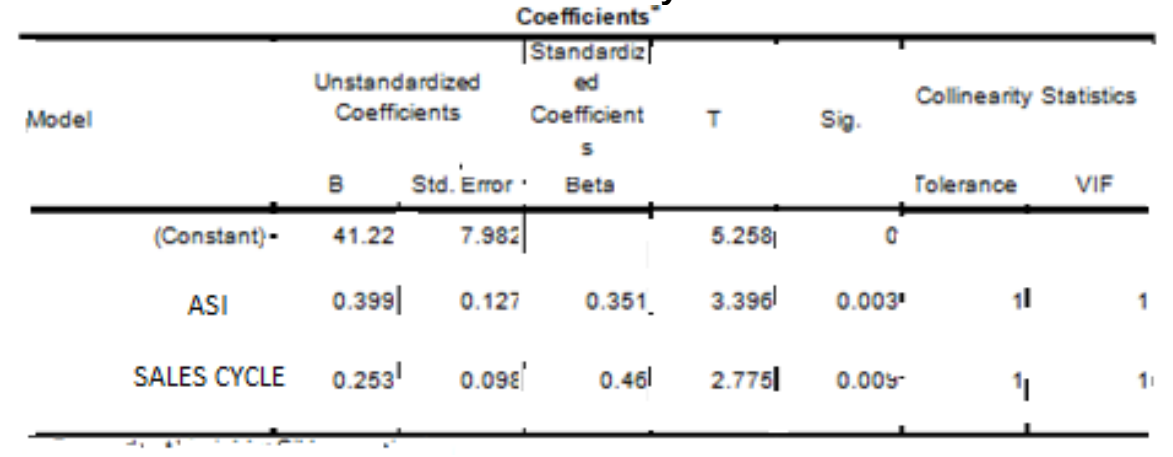

Source: SPSS Data Processing Results 2

Based on the VIF value as shown in Table IV.27 above, it shows that there is no strong correlation between fellow independent variables, where the VIF value of the two independent variables is still less than 10 so it can be concluded that there is no multicollinearity between the two independent variables, namely between personality and work professionalism.

\section{Heteroscedasticity Test}

The heteroscedasticity test aims to test whether in the regression model there is an inequality of variants from the residuals of one observation to another. To detect the presence or absence of heteroscedasticity, namely by looking at the plot graph between the predicted value of the dependent variable (ZPRED) and its residual value (SDRESID). If there is a clear pattern and the dots spread above and below the 0 on the $Y$ axis, heteroscedasticity occurs. The results of heteroscedasticity testing in this study can be seen in Figure 2 below: 


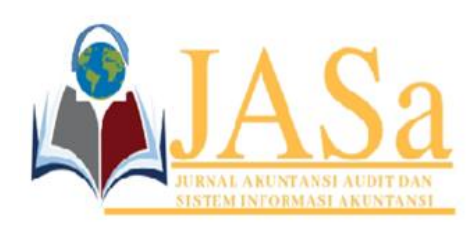

JASa (Jurnal Akuntansi, Audit dan Sistem Informasi Akuntansi)

Vol. 5 No.1/ April 2021

ISSN 2550-0732 print / ISSN 2655-8319 online

DOI; $10.36555 /$ jasa.v5i1.1605

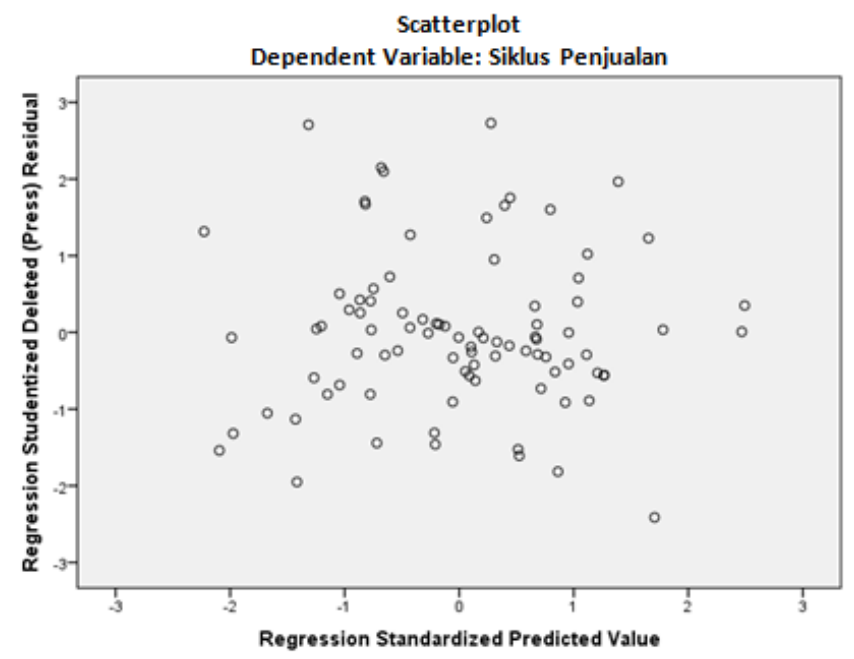

Figure 2. Heteroscedasticity test

Source: SPSS Data Processing Results 2

\section{Multiple Regression Analysis}

Linear regression analysis is used to predict how the value of the dependent variable will change if the value of the independent variable is increased/decreased. Based on the results of data processing using the SPSS version 23.0 tool, the regression results are obtained in table 8 :

Table 8. The results of the regression model estimation

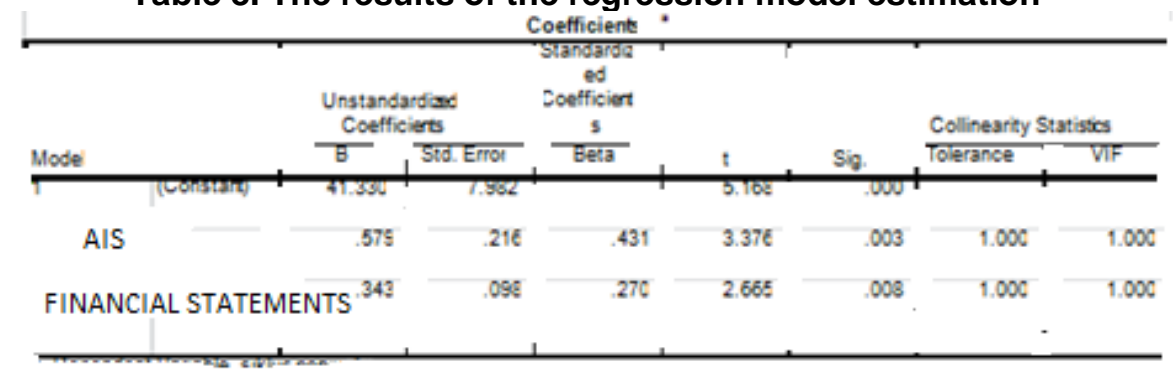

Source: SPSS Data Processing Results 2

Through the results of data processing as shown in Table 8, a regression equation model can be formed as follows.

$$
\hat{Y}=41,330+0.579 x+0.343 y
$$

Based on the regression equation above, it can be interpreted as follows:

The constant value in the equation is 41.330 , indicating that if there is no SIA ( $x 1=0)$ and there is no financial report $(y=0)$, then the sales cycle $(y)$ is 41.330 . The regression coefficient value of the Accounting Information System variable $(x)$ is 0.579 , meaning that if the Accounting Information System increases by one unit, it is predicted that the 


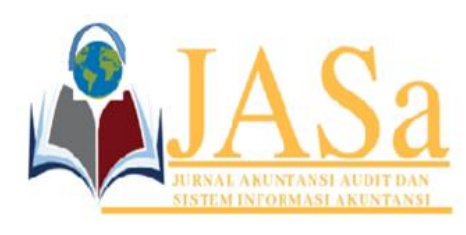

JASa (Jurnal Akuntansi, Audit dan Sistem Informasi Akuntansi)

Vol. 5 No.1/ April 2021

ISSN 2550-0732 print / ISSN 2655-8319 online

DOI; $10.36555 /$ jasa.v5i1.1605

sales cycle will increase by 0.579 units, assuming the other independent variables are constant. The regression coefficient value of the financial statement variable $(y)$ is 0.343 , meaning that if professionalism increases by one unit, it is predicted that the performance appraisal will increase by 0.343 units, assuming the other independent variables are constant.

\section{F test}

To test the above hypothesis, the F-test statistic obtained through the ANOVA table is used as listed in the following table:

Table 9. $\mathrm{F}$ test output in the ANOVA table

\begin{tabular}{lrrrrrr}
\hline Model & Sum of Squares & df & & Mean Square & F & Siq. \\
\hline Regression & 405,627 & 2 & 202,813 & 9,804 &, $000^{b}$ \\
Residual & 2006,533 & 97 & 20,686 & & \\
Total & 2412,160 & 99 & & & \\
\hline
\end{tabular}

Source: SPSS Data Processing Results 2

Based on Table 9 above, it is known that the value of F-count (9.804)> F-table (3.09), thus there is an influence between the accounting information system on financial reports in the sales cycle and the regression model above is feasible and correct.

\section{The Effect of AIS on Financial Statements}

Provisional research results, that SIA affects the financial statements at PT. Puteramas Teguh Jaya, because of these allegations the researchers set the research hypothesis for two-party testing with the following hypothesis formulations:

Ho: All $\beta \neq 0$ : SIA affects the financial statements at PT. Puteramas Teguh Jaya. Ha: All $\beta \neq 0$ : SIA affects the Sales Cycle at PT. Puteramas Teguh Jaya.

To test the above hypothesis, the t-test statistic obtained through the table is used as listed in Table IV.28 below: 


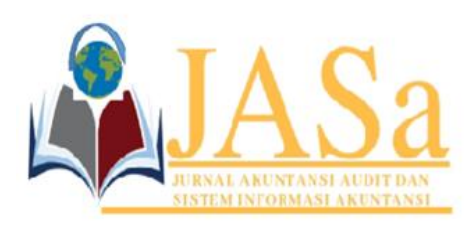

JASa (Jurnal Akuntansi, Audit dan Sistem Informasi Akuntansi)

Vol. 5 No.1/ April 2021

ISSN 2550-0732 print / ISSN 2655-8319 online

DOI; $10.36555 /$ jasa.v5i1.1605

Table 10. partial significance test results (TEST) of accounting information systems in financial reports

\begin{tabular}{|c|c|c|c|c|c|c|c|c|}
\hline \multicolumn{9}{|c|}{ Coefficients $^{\mathrm{a}}$} \\
\hline \multirow{2}{*}{\multicolumn{2}{|c|}{ Model }} & \multicolumn{2}{|c|}{$\begin{array}{l}\text { Unstandardized } \\
\text { Coefficients }\end{array}$} & \multirow{2}{*}{$\begin{array}{c}\text { Standardiz } \\
\text { ed } \\
\text { Coefficient } \\
\underline{s} \\
\text { Beta }\end{array}$} & \multirow[t]{2}{*}{$\mathrm{T}$} & \multirow{2}{*}{ Sig. } & \multicolumn{2}{|c|}{$\begin{array}{l}\text { Collinearity } \\
\text { Statistics }\end{array}$} \\
\hline & & B & Std. Error & & & & $\begin{array}{c}\text { Toleran } \\
\mathrm{ce} \\
\end{array}$ & VIF \\
\hline & (Constant) & 41.130 & 7.872 & & 5.168 & .000 & & \\
\hline \multirow[t]{2}{*}{1} & AIS & .379 & .126 & .331 & 3.386 & .002 & 1.000 & 1.000 \\
\hline & FINANCIAL REPORT & .243 & .098 & .270 & 2.665 & .009 & 1.000 & 1.000 \\
\hline
\end{tabular}

Source: SPSS Data Processing Results 2

Based on data processing using SPSS as presented in Table 10, the t value of the SIA variable was obtained at 3.386 . Because the value of $t$ count (3.386) is greater than $t$ table (1.987934), then at an error level of $5 \%$ it was decided to reject Ho so that Ha was accepted, meaning that with a $95 \%$ confidence level it can be concluded that SIA partially has a significant effect on financial statements. The results of this test provide empirical evidence that a good accounting information system will improve financial reports at PT. Puteramas Teguh Jaya.

\section{The Effect of AIS on the Sales Cycle}

The provisional research results show that the accounting information system has an effect on the sales cycle because of this assumption the researcher sets the research hypothesis for two-party testing with the following hypothesis formulations: Ho: All $\beta \neq 0$ : SIA has no effect on the Sales Cycle at PT. Puteramas Teguh Jaya. Ha: All $\beta \neq 0$ : SIA affects the Sales Cycle at PT. Puteramas Teguh Jaya.

To test the above hypothesis, the t-test statistic obtained through the table is used as listed in Table IV.28 below: 


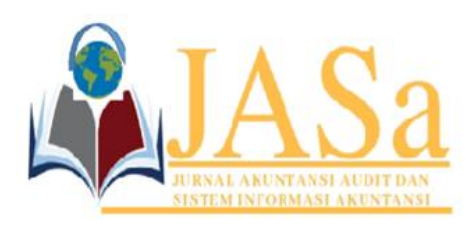
JASa (Jurnal Akuntansi, Audit dan Sistem Informasi Akuntansi)
Vol. 5 No.1/ April 2021
ISSN 2550-0732 print / ISSN 2655-8319 online
DOI; $10.36555 /$ jasa.v5i1.1605

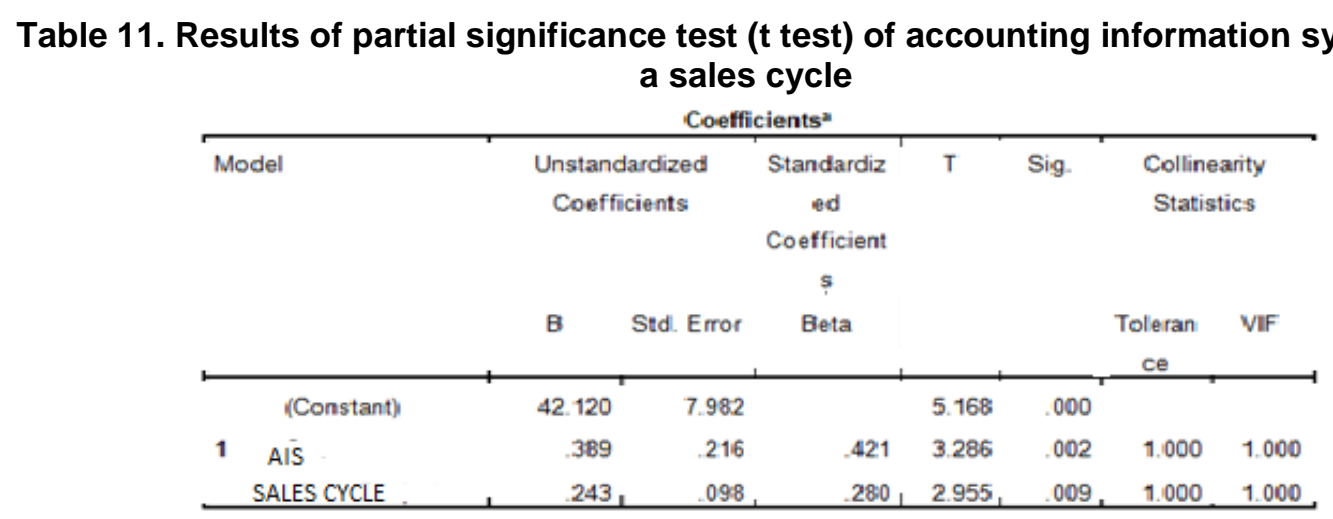

Source: SPSS Data Processing Results 2

Based on data processing using SPSS as presented in Table 11, the t count value of the accounting information system variable is 2.955 . Because the value of t count (2.955) is greater than t table (1.987934), at a 5\% error level it was decided to reject $\mathrm{Ho}$ so that $\mathrm{Ha}$ was accepted, meaning that with a $95 \%$ confidence level it can be concluded that the accounting information system partially has a significant effect on the sales cycle. . The results of this test provide empirical evidence that a good accounting information system will increase the sales cycle at PT. Puteramas Teguh Jaya.

\section{Coefficient of Determination}

Determination coefficient analysis is used to see how much the independent variable affects the dependent variable which is expressed as a percentage. Based on the results of data processing using the SPSS version 23.0 tool, the following results were obtained:

Table 12 the coefficient of determination

\begin{tabular}{|c|c|c|c|c|c|}
\hline Model & $\mathrm{R}$ & R Square & $\begin{array}{c}\text { Adjusted R } \\
\text { Square } \\
\end{array}$ & $\begin{array}{c}\text { Std. Error of the } \\
\text { Estimate }\end{array}$ & Durbin-Watson \\
\hline 1 & $427^{a}$ & .184 & .189 & 7.75082 & 1.937 \\
\hline
\end{tabular}

Source: SPSS Data Processing Results 2

Based on the summary model, the value of Adjusted $R$ Square is 0.189 , these results indicate that the amount of the accounting information system for financial statements in the sales cycle is $18.9 \%$ and the remaining $82.1 \%$ is influenced by other variables not included in this research model. 


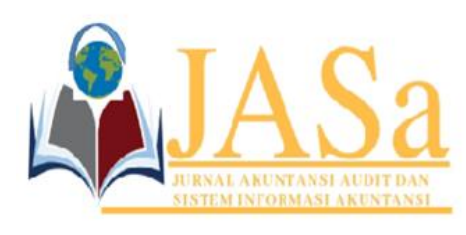

JASa (Jurnal Akuntansi, Audit dan Sistem Informasi Akuntansi)

Vol. 5 No.1/ April 2021

ISSN 2550-0732 print / ISSN 2655-8319 online

DOI; $10.36555 /$ jasa.v5i1.1605

\section{CONCLUSION}

From the research results that have been described, the following conclusions are obtained: Respondents' responses regarding the variables of this study fall into the high category with an average value of the accounting information system variable of $93 \%$, financial reports of $83 \%$ and of the sales cycle of $95 \%$. The results of the path analysis found that there was a significant relationship between the accounting information system and financial reports as well as the provision of knowledge of entrepreneurial competence with the support of stakeholders with a strong enough relationship. The relationship between $X$ and $Y$ is 0.49 and the relationship between $X$ and $Z$ is 0.582 with a strong enough relationship. $56.0 \%$ can be explained by other variables not examined. The results of the analysis also found that the accounting information system (t-count $=7.982$ ) and both of them were also found to have a significant effect on the sales cycle simultaneously.

Azhar Susanto. (2015). Sistem

REFERENCES

Nugroho,Widjajanto.2016.Sistem

Informasi Akuntansi. Bandung: Informasi Akuntansi, Erlangga,

Lingga Jaya. Jakarta.

Jogiyanto. Dr. (2008). Analisis dan desain sistem informasi pendekatan terstruktur. Teori dan praktik aplikasi bisnis. Yogyakarta: Andi Offset.

Romney, Marshall B. dan Steinbart, (2015), "Sistem Informasi Akuntansi", Edisi13, alihbahasa: Kikin Sakinah Nur Safira dan Novita Puspasari, Salemba Empat. Jakarta.

Marshall B. Romney dan Paul John Steinbart. (2014) Sistem Informasi Akuntansi: Accounting Information Systems (Edisi 13), Prentice Hall

Siregar, Syofian. (2016). Statistika Deskriptif untuk Penelitian DilengkapiPerhitungan Manual dan Aplikasi SPSS Versi 17. Jakarta: PT Raja Grafindo Persada

Ikatan Akuntansi Indonesia. (2009). Standar No. 1 : Penyajian Laporan keuangan.

Akuntansi Keuangan, PSAK Jakarta : Salemba Empat. 